\title{
The Relationship between Critical Thinking and Knowledge Acquisition: The Role of Digital Mind Maps-PBL Strategies
}

\author{
Nurkhairo Hidayati, Siti Zubaidah, Endang Suarsini, and Henry Praherdhiono
}

\begin{abstract}
Critical thinking is rational and reflective thinking involved in decision making. Knowledge acquisition refers to the level achieved by students in understanding the materials and meaning of the learning context. Critical thinking and knowledge acquisition can be enriched through applications of relevant learning strategies. The aim of this study was to investigate the correlation between critical thinking and knowledge acquisition in the process of implementing Digital Mind Maps-Problem Based Learning (Digital Mind Maps-PBL) The learning process was conducted to students from Universitas Islam Riau, Indonesia, who were enrolled in the even semester of 2018 in biology education department . The instrument used to measure the students' critical thinking and knowledge acquisition, that was in the form of essay tests, had been confirmed valid by the result of the Pearson Product Moment analysis. The reliability test using Cronbach's Alpha also showed that this instrument was reliable for measuring critical thinking and knowledge acquisition (correlation coefficients are 0.837 and 0.872 , respectively). The results of the study indicated that critical thinking and knowledge acquisition were correlated with a value of 0.861 and a determination coefficient of 0.742 , where $Y=1.215 X-4.323$. It can be concluded that Digital Mind Maps-PBL strategies can be used to refine students' critical thinking, which may result in the improvement of students' knowledge acquisition. Therefore, the implementation of Digital Mind Maps-PBL strategies in the classroom is highly recommended.
\end{abstract}

Index Terms-Critical thinking, digital mind maps-PBL, knowledge acquisition.

\section{INTRODUCTION}

Changes and increasingly abundant information flow in the 21 st century require universities to equip their graduates with sufficient competence. One of the goals of higher education is to promote students' critical thinking. The ability to think critically is a quality sought by most employers in the work field [1]. As an educational institution, universities have to place critical thinking as a crucial foundation for the students to adapt to daily personal, social, and professional demands [2]. Thus, all components involved in education need to implant effective and critical thoughts in students rather than emphasizing facts memorization [3].

Literature has explained various definitions of critical

Manuscript received October 5, 2019; revised December 19, 2019. This work was supported in part the Educational Fund Management Institution (LPDP), the Ministry of Finance of Indonesia.

The authors are with Universitas Negeri Malang, Indonesia and a lecturer at Universitas Islam Riau, Indonesia, 65145, Indonesia (e-mail: khairobo@edu.uir.ac.id, siti.zubaidah.fmipa@um.ac.id ending.suarsini.fmipa@um.ac.id, henry.praherdhiono.fip@um.ac.id). thinking. Critical thinking is often defined as the ability to think in an unorthodox way, see situations from a different point of view, and contemplate beyond expectations to find solutions [4]. From Facione's [5] perspective, critical thinking is comprised of objective decisive judgment on what to believe or what to do in a certain context. Critical thinking is also perceived as a cognitive skill that is associated with logical analyses and argument evaluations [6], [7] to determine logical acts [8].

Critical thinking has been identified as one of the important life skills that can facilitate access to information in life and overcome difficulties [9], as well as help students, develop the skills needed to compete economically in a global society [1]. Critical thinking emphasizes logical interpretations that contribute to students' social and academic lives [10]. Besides, critical thinking also helps students in dealing with social, scientific, and functional problems, filtering information correctly, enabling them to search for truth in various events to achieve a complete understanding of things [11].

The quality of students' critical thinking can have an impact on their knowledge acquisition [12], [13]. Knowledge acquisition is the ability of students to grasp facts and principles in the materials being learned [14], based on the results of the tests conducted by the students. Knowledge acquisition is usually expressed in score achievement [15]. Knowledge acquisition is not just memorizing information but understanding meaning [16] so that it is flexible and not determined by certain types of problems [17].

The correlation between critical thinking and knowledge acquisition shows that knowledge must be achieved appropriately as a result of understanding and justification through critical thinking [18]. In addition, critical thinking is also part of cognitive abilities that involve the acquisition of knowledge in analyzing, interpreting, and inferring information to make the right decisions [13]. Critical thinking entails considerations of different evidence. Better critical thinking will lead to better knowledge acquisition and conclusion drawing [19]. Prior to conclusion drawing, alternatives to solutions need to be formulated so that problems can be solved, hypotheses can be projected, plans can be developed, and goals can be achieved. These activities can help increase an understanding of the problems being faced [12].

A number of studies on critical thinking have been conducted. Critical thinking was used as a predictor in determining students' academic success [2], [20]-[22]. Furthermore, Nasrabadi, Mousavi, \& Farsan [23] showed that critical thinking could contribute to students' mastery of 
learning materials. A positive relationship between critical thinking and knowledge acquisition has been reported by many studies (see, for example, [24], [25]); however, Mahmoud [26] found that there was no significant correlation between critical thinking and nursing students' academic achievement. Moreover, Aghaei, Souri, \& Ghanbari [27] and Zhang \& Lambert [28] also suggest that there was no relationship between critical thinking and academic achievement.

The main requirement for the improvement of students' critical thinking and knowledge acquisition is the students' active involvement in learning. This can be met through active learning strategies that facilitate cognitive processes [29]. Problem Based Learning (PBL) is an active learning strategy that uses contextual and authentic problems [30], [31] to gain knowledge and concepts and develop solutions to problems [32], [33]. PBL orients students to the problem and at the end, leads the students to reflect on the problem-solving process [34], [35].

PBL has been proven effective in developing students' critical thinking. For instance, Gholami et al. [36] found significant changes in students' critical thinking scores after applying PBL with $(P<0.01)$ and evaluation and deduction sub-scales $(P<0.05)$. Similar studies were also conducted at various levels of education [37]-[39]. Besides critical thinking, PBL has also been proven able to increase students' knowledge acquisition [17], [40], [41].

The positive properties of PBL have, needless to say, become a determining factor in the students' increased critical thinking and knowledge acquisition. However, that does not necessarily mean that PBL will always have a significant impact on students' critical thinking and knowledge acquisition. Some studies even showed that PBL did not differ significantly from traditional learning in improving students' knowledge [42]-[44]. Therefore, in this study, PBL was combined with Digital Mind Maps (DMM) to support students' knowledge acquisition during the learning process.

Digital Mind Maps (DMM) are information technology-based mind maps that assist students in presenting their ideas using a variety of features [45]. DMM feature unique fonts, images, videos, links insertion, colors, hierarchy, boundaries, and others. Students can compile a radial digital mind map by placing the main idea in the middle and other interrelated concepts surrounding it [46]. Mind maps can improve the ability of students to remember and link concepts because they contain varied colors and branches [47].

Learning process that is empowered by integrated PBL-DMM strategies is expected to promote critical thinking and knowledge acquisition in university classrooms. The integration of PBL-DMM strategies into learning has been conducted at university levels to improve creativity [48]. In addition, a number of studies have proven that both PBL and mind maps play a crucial role in the development of students' critical thinking and knowledge acquisition [36], [38], [49]. University students need both critical thinking and knowledge acquisition because an increase in critical thinking will lead to an increase in knowledge acquisition.

The relationship between critical thinking and knowledge acquisition has been explained in many studies. The findings from these studies indicate a diversity where some argued that critical thinking has a significant correlation with students' knowledge acquisition, while some others pointed out the opposite. Besides this controversy, this study was conducted also based on the reason that there has not been a study reporting the link between critical thinking and knowledge acquisition using Digital Mind Maps-PBL learning strategies. The current study specifically aimed to examine the relationship between critical thinking and knowledge acquisition through Digital Mind Maps-PBL strategies and thus provide empirical evidence to prove the relationship between the two variables

\section{MeTHODS}

\section{A. Design of the Study}

A correlational design was employed to examine the relationship between critical thinking and knowledge acquisition, where critical thinking served as the predictor while knowledge acquisition functioned as the criterion. This study was conducted at the Department of Biology Education of Universitas Islam Riau, Indonesia. The participants of this study consisted of the students who were enrolled in the program in the even semester of 2018 academic year in biology education program. Digital Mind Maps-PBL learning strategies were implemented in the classroom for one semester with 16 meetings, and after the learning process ended, essay tests were administered to evaluate the students' critical thinking and knowledge acquisition.

The learning process was carried out in six stages. At the first stage, the students were given a topic and instructed to compose a digital mind map related to the topic. This was done to enable the students to link their prior knowledge with the material being learned at the time. At the second stage, the students were asked to formulate problems based on actual issues presented by the lecturer. The students were allowed to sit in groups to solve the problems at the third stage, and at the fourth stage, the students started to collect relevant information to obtain explanations on the problems. At the fifth stage, the students wrote a report containing solutions to the problems, and at the sixth stage, the students were asked to do some reflection and evaluations on the problem-solving process they had gone through since the beginning.

\section{B. Instrument of the Study}

The students' critical thinking and knowledge acquisition were measured using essay tests. The instruments had been validated using Pearson product-moment and Cronbach's Alpha reliability tests. The results of the validity and reliability tests showed that all test items were valid and reliable, with a score of 0.837 for critical thinking and of 0.872 for knowledge acquisition. The critical thinking instrument was comprised of several indicators, namely basic clarification, bases for a decision, inference, advanced clarification, supposition and integration, strategies and tactic, and the knowledge acquisition instrument referred to Anderson \& Krathwohl's revised Bloom's taxonomy levels. 


\section{Data Collection and Data Analysis}

The critical thinking and knowledge acquisition data were gathered by administering essay tests to the students. The students' test answers were scored based on indicators set in the selected rubric. The data were then analyzed using Pearson Product Moment Coefficient of Correlation and regression analyses to determine the significance of the relationship between the two variables. Before conducting a regression analysis, the normality and homogeneity of the data were tested. The results of the prerequisite tests showed that the critical thinking data were distributed normally and homogeneously with p-values of 0.097 and 0.055, respectively. In addition, the knowledge acquisition data were also assumed normal and homogeneous with p-values of 0.200 and 0.057 , respectively.

\section{FINDINGS}

The result of the regression analysis suggesting the significance of the relationship between critical thinking and knowledge acquisition was summarized in Table I.

TABLE I: THE RESULT OF THE REGRESSION ANALYSIS

\begin{tabular}{lcccc}
\hline \hline Model & $\mathrm{R}$ & R Square & $\begin{array}{c}\text { Adjusted R } \\
\text { Square }\end{array}$ & $\begin{array}{c}\text { Std. Error of the } \\
\text { Estimate }\end{array}$ \\
\hline 1 & $\begin{array}{c}.861^{\mathrm{a}} \\
\text { a. Predictors: (Constant), CRI_DMM-PBL }\end{array}$ & .742 & .734 & 5.12617 \\
\hline \hline
\end{tabular}

Table I reported a correlation value of 0.861 and a $\mathrm{R}$-square value of 0.742 . These figures suggested that $74.20 \%$ of the students' knowledge acquisition was affected by their critical thinking qualities while the rest $(25.8 \%)$ was determined by other factors. The regression equation for this relationship was $\mathrm{Y}=1.215 \mathrm{X}-4.323$. The correlation between critical thinking as the predictor and knowledge acquisition as the criterion at the $5 \%$ alpha $(\alpha)$ level can be seen in Table II.

TABLE II: THE RESULT OF THE F-TEST ANALYSIS

\begin{tabular}{lllllll}
\hline \multicolumn{7}{c}{ TABLE II: THE RESULT OF THE F-TEST ANALYSIS } \\
\hline Model & $\begin{array}{c}\text { Sum of } \\
\text { Square }\end{array}$ & Df & $\begin{array}{c}\text { Mean } \\
\text { Square }\end{array}$ & F & Sig. \\
\hline 1 & Regression & 2489.595 & 1 & 2489.595 & 94.742 & $.000^{\mathrm{a}}$ \\
& Residual & 867.161 & 33 & 26.278 & & \\
Total & 3356.757 & 34 & & & \\
a. Predictors: (Constant), critical thinking \\
b., Dependent Variable: knowledge acquisition
\end{tabular}

Table II showed that F-calculated was 26.278 and the significance level was $0.000<\alpha(\alpha=0.05)$. It indicated that critical thinking and knowledge acquisition were significantly correlated. The regression equation obtained can be used to predict students' achievement in knowledge acquisition.

\section{DisCUSSIONS}

The findings from this study showed that critical thinking had a correlation with the students' knowledge acquisition. An increase in the quality of the students' critical thinking was followed by an increase in the students' knowledge acquisition. The students were able to master the concept being learned because the Digital Mind Maps-PBL learning strategies implemented in this study required the students to use their rational and intuitive abilities. The DMM-PBL strategies were aimed at problem-solving and therefore demanded the students to apply their thinking abilities in utilizing various learning resources to find solutions. During the process of searching for the relevant resources, the students read a lot of information. As a result, their knowledge was enriched. Similarly, research has shown that problem-based learning strategies can improve students' critical thinking abilities [50], [51]

Aside from being problem-oriented, the Digital Mind Maps-PBL learning strategies also involved DMM creation activity. Since the students were required to compose a digital mind map on their own, they had to read various references related to the topic and sort important information to place as keywords in their DMM. This activity can stimulate the students' critical thinking because critical thinking involves the process of analyzing various information obtained through knowledge construction. Conceptual knowledge is the result of a constructive process. Therefore, the quality of critical thinking can show good knowledge acquisition [18]. A learning process that is based on critical thinking will require students to think carefully to use rational abilities and intuition so that they are able to master the concept being learned [52].

In addition, the results of this study also showed that critical thinking contributed $74.20 \%$ to knowledge acquisition. Many researchers argue that critical thinking can be used as a reliable predictor of one's knowledge acquisition. Students with higher levels of critical thinking are able to process, organize, deduce, infer, and explore information in a more effective way and are usually open to better experiences. As a result, they can possess better knowledge acquisition [53]. Bakhtiar Nasrabadi, Mousavi, \& Alibakhshi [54] add that critical thinking can encourage students to express their perspectives in a distinct manner and adopt a more logical method of dealing with problems that enable them to acquire knowledge.

It should be noted that knowledge acquisition is not only affected by critical thinking, but also other factors (25.80\%), such a metacognition skills, learning motivation, and learning styles. This finding is confirmed by Bahri and Corebima [55], who found that motivation and metacognition skills simultaneously contribute to student learning outcomes. Likewise, knowledge acquisition also depends on students' learning styles [41]. Learning styles play an important role in students' academic achievement because they encourage students to be holistic and at ease to interact with other students [56]. High motivation drives students to be more attentive to learning so that they are able to understand learning materials better [57]. Metacognition skills allow students to become responsible for the tasks given so that in the end the students are able to master the concepts being learned [58].

The problem-solving process undergone by the students also triggers the relationship between critical thinking and knowledge acquisition. Problem-solving activities encourage 
students to think and find the right solution. Critical thinking can help someone to consider various points of view to make the right decision based on careful, systematic, and logical efforts. Critical thinking can also provide an appropriate direction in thinking and working, and assist in determining the relationship between one thing and another more accurately [59]. A critical thinker can be identified in terms of how they approach and solve certain problems. Individuals who have the ability to think critically have several characteristics such as being clear in expressing questions or problems, discipline at work, focused on the problems faced, and preserved in finding relevant information [10].

The correlation between critical thinking and knowledge acquisition can also be explained from critical thinking aspects. For instance, based on the aspects of basic clarification and bases for a decision, students are required to read a variety of literature in order to identify criteria to determine possible and correct answers to problems. Students can acquire more knowledge by reading more texts. This finding is in line with Weinstock \& Cronin's [19] explanation that suggests that critical thinking is an effective way to improve students' understanding of concepts. Students can use critical thinking to understand and apply concepts to achieve good learning outcomes. Critical thinking is also associated with cognitive skills because it involves the activity of solving problems, formulating the factors that influence it, and calculating various possibilities to make the right decision [60], [61].

The results of this study provide an insight for educators to determine which learning strategies are appropriate for their classrooms. During the learning process, educators can focus on improving students' critical thinking by, for example, asking open-ended or ill-structured questions. Educators can improve students' knowledge acquisition by facilitating their critical thinking. Because of that, the results of this study contribute to the improvement of learning quality.

The relationship between critical thinking and knowledge acquisition analyzed through Digital Mind Maps-PBL implemented in this study showed that critical thinking and knowledge acquisition could be promoted in the classroom simultaneously. Critical thinking is related to the ability to analyze information to determine the right decision and knowledge acquisition is associated with the level of success in understanding meaning or information. All efforts made to improve critical thinking will also be effective in improving knowledge acquisition. Despite the significance, the findings of this study can only be generalized to other populations from tertiary levels of education and therefore, future research needs to be conducted at the primary and secondary levels of education.

\section{CONCLUSION}

It can be concluded that there is a significant correlation between critical thinking and knowledge acquisition through the implementation of Digital Mind Maps-PBL learning strategies. An increase in the students' critical thinking was followed by an increase in the students' knowledge acquisition. Therefore, educators can simultaneously improve these two variables (critical thinking and knowledge acquisition) during the learning process. Unfortunately, this study only examined the correlation between critical thinking and knowledge acquisition at the tertiary level of education. Therefore, further research can be carried out at different levels of education, for example, in secondary or even elementary schools to get a clearer picture of the relationship between critical thinking and knowledge acquisition among participants of different ages.

\section{CONFLICT OF INTEREST}

We certify that there is no actual or potential conflict of interest in relation to this article.

\section{AUTHOR CONTRIBUTIONS}

Hidayati designed and formulated research goals and objectives as a whole, determined the right method, and presented the results of the study. Zubaidah is responsible for conducting research and supervision, as well as providing input to the manuscript being written. Suarsini contributed to enriching references and reviewing manuscripts. Praherdhiono participated in critically revising the manuscript for the content discussed

\section{ACKNOWLEDGEMENTS}

Authors would like to thank the Educational Fund Management Institution (LPDP), the Ministry of Finance of Indonesia with number FR2712018124893 the Ministry of Research, Technology, and Higher Education of the Republic of Indonesia.

\section{REFERENCES}

[1] K. Changwong, A. Sukkamart., and B. Sisan, "Critical thinking skill development: Analysis of a new learning management model for Thai high schools," Journal of International Studies, vol. 11, no. 2, pp. 37-48, 2018.

[2] C. J. Fong, Y. Kim, C. W. Davis, T. Hoang, and Y. W. Kim, “A meta-analysis on critical thinking and community college student achievement," Thinking Skills and Creativity, vol. 26, pp. 71-83, 2017.

[3] A. Karbalaei. (2012). Critical thinking and academic achievement Íkala, revista de lenguaje y cultura, 17(2), 121-128.

[4] K. P. Acharya, "Exploring critical thinking for secondary level students in Chemistry: From insight to practice," Journal of Advanced College of Engineering and Management, vol. 3, pp. 31-39, 2017.

[5] P. A. Facione, "The disposition toward critical thinking: Its character, measurement, and relation to critical thinking skill," Informal Logic, vol. 20, 1, pp. 61-84, 2000.

[6] C. A. Giancarlo and P. A. Facione, "A look across four years at the disposition toward critical thinking disposition among undergraduate students," The Journal of General Education, vol. 50, no. 1, pp. 29-55, 2001.

[7] R. H. Stupnisky, R. D. Renaud, L. M. Daniels, T. L. Haynes, and R. P. Perry, "The interrelation of first-year college students' critical thinking disposition, perceived academic control, and academic achievement," Research in Higher Education, vol. 49, no. 6, pp. 513-30, 2008.

[8] M. Gusic et al., "Milestones of critical thinking: A developmental model for medicine and nursing," Academic Medicine, vol. 89, no. 5, pp. 715-720, 2014.

[9] Z. Ghazivakili, R. N. Nia, F. Panahi, M. Karimi, H. Gholsorkhi, and Z. Ahmadi, "The role of critical thinking skills and learning styles of university students in their academic performance," Journal of Advances in Medical Education \& Professionalism, vol. 2, no. 3, p. 95, 2014.

[10] M. J. Sharifi, J. Fathabadi, A. Karimi, and M. Sharifi, "The effectiveness of teaching critical thinking skills on students' Academic achievement in mathematics and science: A study in timss framework," Iranian Journal of Learning and Memory, vol. 1, no. 1, pp. 19-26, 2018.

[11] S. A. R. Magrabi, M. I. Pasha, and M. Y. Pasha, "Classroom teaching to enhance critical thinking and problem-solving skills for developing 
IOT applications," Journal of Engineering Education Transformations, vol. 31, no. 3, pp. 152-157, 2018.

[12] N. M. Chan, Ho, T. Irene, and Y. L. Ku, "Epistemic beliefs and critical thinking of Chinese students," Learning and Individual Differences, vol. 21, pp. 67-77, 2011.

[13] C. R. Friede, T. A. Irani, E. B. Rhoades, N. E. Fuhrman, and M. Gallo, "It's in the genes: Exploring relationships between critical thinking and problem solving in undergraduate agriscience students' solutions to problems in mendelian genetics," Journal of Agricultural Education, vol. 49, no. 4, pp. 25-37, 2008.

[14] B. Rittle-Johnson and J. R. Star, "Compared with what? The effects of different comparisons on conceptual knowledge and procedural flexibility for equation solving," Journal of Educational Psychology, vol. 101, no. 3, p. 529, 2009.

[15] H. Y. Feng, J. J Fan, and H. Z. Yang, "The relationship of learning motivation and achievement in EFL: Gender as an intermediated variable," Educational Research International, vol. 2, no. 2, pp. 50-58, 2013.

[16] H. E. Zuya, "Prospective teachers' conceptual and procedural knowledge in mathematics: The case of Algebra," American Journal of Educational Research, vol. 5, no. 3, pp. 310-315, 2017.

[17] M. Wijnen, S. M. M. Loyens, and L. Schaap, "Experimental evidence of the relative effectiveness of problem-based learning for knowledge acquisition and retention," Interactive Learning Environments, vol. 24, no. 8, pp. 1907-1921, 2016.

[18] C. Andreou, E. Papastavrou, and A. Merkouris, "Learning styles and critical thinking relationship in baccalaureate nursing education: A systematic review," Nurse Education Today, vol. 34, no. 3, pp. 362-371 2014.

[19] M. Weinstock and M. A. Cronin, "The everyday production of knowledge: Individual differences in epistemological understanding and juror-reasoning skill," Applied Cognitive Psychology, vol. 17, no. 2 , pp. $161-181,2003$.

[20] J. Ashoori, "Relationship between self-efficacy, critical thinking, thinking styles and emotional intelligence with academic achievemen in nursing students," Scientific Journal of Hamadan Nursing \& Midwifery Faculty, vol. 22, no. 3, pp. 15-23, 2014.

[21] L. O'Hare and C. McGuinness, "Measuring critical thinking, intelligence, and academic performance in psychology undergraduates," The Irish Journal of Psychology, vol. 30, no. 3-4, pp. 123-131, 2009.

[22] V. Sepahi, M. R. Khazaei, A. Khoshy, S. Iranfar, and M. Timare, "The correlation between critical thinking disposition and academic achievement of preclinical and clinical medical students at Kermanshah University of Medical Sciences," Educational Researches of Medical Sciences, vol. 3, no. 1, pp. 10-15, 2014.

[23] H. A. Nasrabadi, S. Mousavi, and Z. K. Farsan, "The contribution of critical thinking attitude and cognitive learning styles in predicting academic achievement of medical university's students," Iranian Journal of Medical Education, vol. 12, no. 4, pp. 285-296, 2012.

[24] A. Ghanizadeh, "The interplay between reective thinking, critical thinking, self-monitoring, and academic achievement in higher education," Higher Education, vol. 74, no. 1, pp. 101-114, 2017.

[25] D. Ross, K. Leof er, S. Schipper, B. Vandermeer, and G. M. Allan, "Do scores on three com- monly used measures of critical thinking correlates with academic success of health profes- sions trainees: A systematic review and meta-analysis," Academic Medicine, vol. 88, no. 5, pp. 724-734, 2013

[26] H. G. Mahmoud, "Critical thinking dispositions and learning styles of baccalaureate nursing students and its relation to their achievement," International Journal of Learning and Development, vol. 2, no. 1, pp. $398-415,2012$

[27] N. Aghaei, R. Souri, and S. Ghanbari, "Comparison of the relationship between critical thinking and academic achieve- ment among physical education students and students in other fields of study in Bu Ali Sina University, Hamedan," Management of Sport and Movement Sciences, vol. 2, no. 4, pp. 35-45, 2012.

[28] H. Zhang and V. Lambert, "Critical thinking dispositions and learning styles of baccalaureate nursing students from China," Nursing and Health Sciences, vol. 10, pp. 175-181, 2008.

[29] S. Dehghanzadeh and F. Jafaraghaee, "Comparing the effects of traditional lecture and flipped classroom on nursing students' critical thinking disposition: A quasi-experimental study," Nurse Education Today, vol. 71, pp. 151-156, 2018.

[30] M. S. Carriger, "Problem-based learning and management development - Empirical and theoretical considerations," International Journal of Management Education, vol. 13, no. 3, pp. 249-259, 2015.
[31] W. Hung, K. Mehl, and J. B. Holen, "The relationships between problem design and learning process in problem-based learning environments: Two cases," The Asia-Pacific Education Researcher, vol. 22, no. 4, pp. 635-645, 2013.

[32] A. EL-Shaer and H. Gaber, "Impact of problem-based learning on student critical thinking dispositions, knowledge acquisition and retention," Journal of Education and Practice, vol. 5, no. 14, pp. 74-85, 2014.

[33] Y. H. Hu, J. Xing, and L. P. Tu, "The effect of a problem-oriented teaching method on university mathematics learning," Eurasia Journal of Mathematics, Science and Technology Education, vol. 14, no. 5, pp. 1695-1703, 2018

[34] R. I. Arends, Learning to Teach, New York, McGraww-Hill, 2012.

[35] J. Savery, "Overview of problem-based learning: Definitions and distinctions," Interdisciplinary Journal of Problem Based Learning, vol. 1, no. 1, pp. 269-282, 2006.

[36] M. Gholami, P. K. Moghadam, F. Mohammadipoor, M. J. Tarahi, M. Sak, T. Toulabi, and A. H. H. Pour, "Comparing the effects of problem-based learning and the traditional lecture method on critical thinking skills and metacognitive awareness in nursing students in a critical care nursing course," Nurse Education Today, vol. 45, pp 16-21, 2016.

[37] G. Gorghiu, L. M. Drăghicescu, S. Cristea, A. M. Petrescu, and L. M. Gorghiu, "Problem-based learning-an efficient learning strategy in the science lessons context," Procedia-Social and Behavioral Sciences, vol. 191, pp. 1865-1870, 2015.

[38] A. S. Mahmoud and H. A. Mohamed, "Critical thinking disposition among nurses working in puplic hospitals at port-said governorate," International Journal of Nursing Sciences, vol. 4, no. 2, pp. 128-134, 2017.

[39] S. Sendağ and F. H. Odabaşı, "Effects of an online problem based learning course on content knowledge acquisition and critical thinking skills," Computers \& Education, vol. 53, no. 1, pp. 132-141, 2009.

[40] S. Baharom and B. Palaniandy, "Problem-based learning: A process for the acquisition of learning and generic skills," PBL across Cultures vol. 47, 2013.

[41] F. Shirazi and S. Heidari, "The relationship between critical thinking skills and learning styles and academic achievement of nursing students," The Journal of Nursing Research, vol. 27, no. 4, p. 38, 2019.

[42] S. C. Cheng, H. C. She, and L. Y. Huang, "The impact of problem-solving instruction on middle school students' physical science learning: Interplays of knowledge, reasoning, and problem solving," Eurasia Journal of Mathematics, Science and Technology Education, vol. 14, no. 3, pp. 731-743, 2018.

[43] B. Matthews, "The effects of direct and problem base learning instruction in an undergraduate introductory engineering graphics course," Uma Ética Para Quantos? Vol. XXXIII, no. 2, pp. 1-197, 2012.

[44] H. G. Schmidt, H. T. Molen, W. W. Winkel, and W. H. Wijnen, "Constructivist, problem-based learning does work: A meta-analysis of curricular comparisons involving a single medical school," Educational Psychologist, vol. 44, no. 4, pp. 227-249, 2009.

[45] H. Faste and H. Lin, "The untapped promise of digital mind maps," in Proc. the SIGCHI Conference on Human Factors in Computing Systems, pp. 1017-1026, 2012

[46] J. Cuthell and C. Preston, "Tracking the stages of learning: Concept maps as representations of liminal space," Themes in Science and Technology Education, vol. 5, no. 1-2, pp. 81-96, 2013.

[47] T. Buzan, Learn to Mind Maps Book, 2011.

[48] N. Hidayati, S. Zubaidah, E, Suarsini, and H. Praherdhiono, "An effective learning model derived from integration problem-based learning and digital mind maps to enhance students' creativity," in Proc. the 2019 3rd International Conference on Education and Multimedia Technology, pp. 369-374, 2019.

[49] I. Papushina, O. Maksimenkova, and A. Kolomiets, "Digital educational mind maps: A computer supported collaborative learning practice on marketing master program," Interactive Collaborative Learning, pp. 17-30, 2017.

[50] M. Y. C. A. Kek and H. Huijser, "The power of problem-based learning in developing critical thinking skills: Preparing students for tomorrow's digital futures in today's classrooms," Higher Education Research and Development, vol. 30, no. 3, pp. 329-341, 2011

[51] M. Niwa, T. Saiki, K. Fujisaki, Y. Suzuki, and P. Evans, "The effects of problem-based-learning on the academic achievements of medical students in one japanese medical school, over a twenty-year period," Health Professions Education, vol. 2, no. 1, pp. 3-9, 2016. 
[52] G. J. Kelly and P. Licona, "Epistemic practices and science education," History, Philosophy and Science Teaching, pp. 139-165, Springer, Cham, 2018.

[53] F. Taghva, N. Rezaei, J. Ghaderi, and R. Taghva, "Studying the relationship between critical thinking skills and students' educational achievement (eghlid universities as case study)," International Letters of Social and Humanistic Sciences, vol. 25, pp. 18-25, 2014.

[54] N. Bakhtiar, S. Mousavi, and F. Alibakhshi, "The role of critical thinking attitude, cognitive ways of learning, and probing in prediction of academic achievement," Quarterly Journal of New Thoughts on Education, vol. 7, no. 4, pp. 115-138, 2011.

[55] A. Bahri and A. D. Corebima, "The contribution of learning motivation and metacognitive skill on cognitive learning outcome of students within different learning strategies," Journal of Baltic Science Education, vol. 14, no. 4, pp. 487-500, 2015.

[56] R. Panahi, S. Kazemi, and A. Rezaie, "The relationship between learning styles and academic achievement: The role of gender and academic discipline," Developmental Psychology (Journal of Iranian Psychologists), vol. 8, no. 30, pp. 189-196, 2012.

[57] A. Rehman and K. Haider, "The impact of motivation on learning of secondary school students in Karachi: An analytical study," Educational Research International, vol. 2, no. 2, pp. 139-147, 2013.

[58] D. J. Hacker, M. C. Keener, and J. C. Kircher, "Writing is applied metacognition," Handbook of metacognition in education, pp. 154-172, 2009.

[59] J. Ashoori, "Relationship between self-efficacy, critical thinking, thinking styles and emotional intelligence with academic achievement in nursing students," Scientific Journal of Hamadan Nursing \& Midwifery Faculty, vol. 22, no. 3, pp. 15-23, 2014.

[60] D. F. Halpern, "Critical thinking workshop for helping our students become better thinker," University of Louisville, 2013

[61] M. G. Erikson and M. Erikson, "Learning outcomes and critical thinking-good intentions in conflict," Studies in Higher Education, pp. $1-11,2018$.

Copyright $\odot 2020$ by the authors. This is an open access article distributed under the Creative Commons Attribution License which permits unrestricted use, distribution, and reproduction in any medium, provided the original work is properly cited (CC BY 4.0).

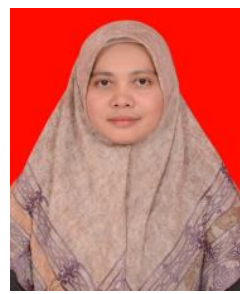

Nurkhairo Hidayati was born in Bangkinang, Indonesia. She is a Ph.D. candidate at Universitas Negeri Malang, Indonesia. She received a bachelor's degree from Universitas Riau and a master degree in Biology Education Department from Universitas Negeri Malang, Indonesia. She currently works as a lecturer at Universitas Islam Riau, Indonesia with a focus on teaching and learning. Mrs. Hidayati research interests focus on how to improve learning experiences. Mainly engaged in Problem Based Learning, critical thinking, creativity and habits of minds.

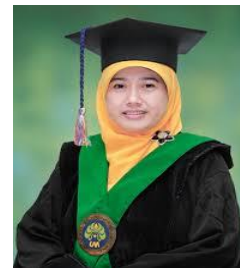

Siti Zubaidah is a professor in genetics at Universitas Negeri Malang, Indonesia. She was born in Malang, East Java province, Indonesia. Zubaidah completed her Ph.D. at Universitas Brawijaya and her master degree studies at Universitas Negeri Malang. Her research interests in the area of genetics, social science, teaching, and learning. She has collaborated actively with researchers in several other disciplines of education, molecular and agriculture. In terms of research, she has more than 20 Scopus publications.

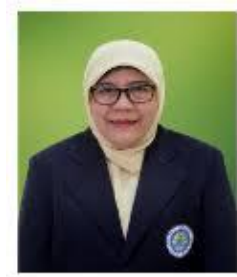

Endang Suarsini was born in April 1953 in Lumjang, Indonesia. She is a doctor from Universitas Negeri Malang, Indonesia. She got the master of basic medical sciences, Universitas Indonesia in 1988. Mainly engaged in microbiology, teaching, and learning research. She has participated in many national and international conferences. The results of her research have also been published in reputable journal.

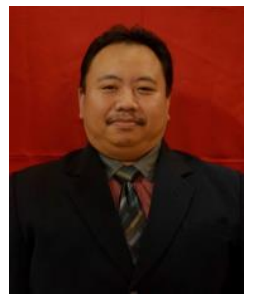

Henry Praherdhino was born in January 1977. He is a lecturer in the educational technology department of Universitas Negeri Malang, Indonesia. $\mathrm{He}$ received a bachelor's degree from Universitas Airlangga, Indonesia in August 2001. He holds a magister of education from Universitas Negeri Malang. Dr. Praherdhiono interests in the area of educational technology, instructional technology and learning environment. He has several articles in reputable journals according to his area of expertise. 